\title{
Concessie of confessie?
}

\section{Argumenten van Willem van Oranje en zijn omgeving voor publieke tolerantie $^{1}$}

\author{
Jurn de Vries
}

\begin{abstract}
Calvijn ging uit van de geestelijke eenheid van kerk en staat. Zijn volgelingen accepteerden geleidelijk de gelijkberechtiging van protestanten en katholieken in de samenleving. Hun argumenten daarvoor waren vooral praktisch van aard. Bijbelse argumenten, zoals de gelijkenis van het onkruid in de akker, speelden slechts een beperkte rol. Pas in de negentiende eeuw werd de publieke tolerantie bij de 'neocalvinisten' een principiële keuze.
\end{abstract}

\section{Vraagstelling en werkwijze}

Tegenwoordig worden in de West-Europese cultuur de politieke vrijheden, inclusief de vrijheid van godsdienst, vrijwel algemeen omarmd, ook door christenen. Ook christenen die ervan overtuigd zijn dat hun geloof de waarheid is, wijzen dwang om anderen tot dat geloof te bewegen uit overtuiging af. Ze beroepen zich daarvoor bijvoorbeeld op de gelijkenis van Jezus over het onkruid in de akker (Matteüs 13:24-30, 36-43). ${ }^{2}$ Wie meteen het onkruid wil uitroeien, loopt gevaar ook het goede gewas uit te trekken, zei Jezus. Laat daarom beide opgroeien tot de oogst; dan kunnen ze alsnog uit elkaar gehaald worden. Die akker is de wereld, zei Jezus erbij. En de oogst staat voor het laatste oordeel bij Jezus' wederkomst.

Deze gelijkenis werd al in de vroege christelijke kerk aangevoerd ten gunste van verdraagzaamheid jegens ketters. ${ }^{3}$ Kerkvaders als Tertullianus, Lactantius en Athanasius wezen dwang in geloofszaken af. Het oordeel wordt aan God overgelaten. ${ }^{4}$ Maar deze gelijkenis heeft niet altijd de houding van christenen tegenover anders- of niet-gelovenden bepaald. Nadat het christendom onder keizer Theodosius I staatsgodsdienst was geworden, ging de mening postvatten die ook in het

1 De woordspeling in de titel is ontleend aan A.A. van Ruler: 'De gewetensvrijheid is noch als concessie noch als experiment, maar alleen als confessie gewaarborgd, en als zoodanig komt zij in slechts één gestalte ter wereld voor, nl. in de gereformeerde religie', uit: Religie en Politiek, Nijkerk 1945, p. 232 = Verzameld Werk VIA, Zoetermeer 2016, p. 154. Hij gebruikte de woordspeling later vaker, zie Verzameld Werk VIA, Zoetermeer 2016, p. 80, noot 468.

2 B.v. G. de Kruijf, Ethiek onderweg - Acht adviezen, Zoetermeer 2008, p. 100.

3 H. Klueting, 'Lasset beides miteinander wachsen bis zur Ernte', in: H. Lademacher e.a. (red.), Ablehung - Duldung - Anerkennung, Toleranz in den Niederlanden und in Deutschland. Ein historischer und aktueller Vergleich, Münster/New York/München/Berlijn 2004, p. 61.

4 H. Berkhof, De kerk en de keizer, Amsterdam 1946, p. 82 e.v., m.n. p. 86. 
oude Romeinse Rijk gold, ${ }^{5}$ dat een politieke eenheid alleen stabiel kon zijn als zij tegelijk een religieuze eenheid was. Gedurende de hele Middeleeuwen hield men vast aan het ideaal van een christelijk gemenebest, ${ }^{6}$ waarin het volk door de burgerlijke en de kerkelijke overheid gezamenlijk werd geregeerd. Een enkeling, zoals Marsilius van Padua (1275/1280-1342/1343), keerde zich tegen de wereldlijke macht van de kerk met een beroep op Johannes 18:36 (waar Jezus zegt: 'Mijn Koninkrijk is niet van deze wereld'). ${ }^{7}$ Dat model van een christelijk gemenebest, het zogenoemde corpus christianum, handhaafde zich tot na de Reformatie, zoals in de stadsrepubliek Genève ten tijde van Johannes Calvijn. Elders in Europa, waar de overheid samenwerkte met de Rooms-Katholieke Kerk, werden Calvijns volgelingen met harde hand bestreden, tot de doodstraf toe. Nadat zij enkele decennia vervolging hadden ondergaan, begonnen onder hen pleidooien te klinken voor politieke tolerantie van verschillende christelijke geloofsrichtingen naast elkaar.

In dit artikel willen we onderzoeken wat de argumenten waren van de volgelingen van Calvijn voor publieke tolerantie in geloofszaken. Waren die vooral praktisch van aard: voor een minderheid is het de enige uitweg? Of speelden ook Bijbelse argumenten, zoals een beroep op de gelijkenis van het onkruid in de akker, een rol? Anders gezegd: was het opgeven van het ideaal van het corpus christianum een concessie aan de omstandigheden of een zaak van principiële overtuiging?

Daarvoor wil ik in dit artikel eerst de overtuiging van Calvijn en zijn leerlingen weergeven ten gunste van een overheid die de eenheid van religie waarborgt. Daarna laat ik zien hoe dat geleidelijk verschuift bij de Franse hugenoten. In de Nederlanden koos Willem van Oranje openlijk voor de geloofsvrijheid. Ik geef aan welke invloed zijn hofpredikers daarop hebben uitgeoefend. Daarna volgen nog enkele opmerkingen over de generatie calvinisten na hen, waarna ik zal afsluiten met het formuleren van een antwoord op mijn vraagstelling.

\section{Reformatie en politieke tolerantie}

Sinds de breuk van Luther met de paus kwam er in het westelijk deel van Europa kerkelijke verdeeldheid. De reactie van de overheden in Duitsland, Frankrijk en Spanje was die met harde hand de kop in te drukken. Luther, die na de rijksdag van Worms (1521) zelf ook vogelvrij verklaard werd, nam hiertegen stelling, niet alleen ten gunste van zijn eigen volgelingen, maar ook van moslims en joden. Zo schreef hij in 1525 onder verwijzing naar de gelijkenis van het onkruid in de akker:

5 Berkhof 1946, 89.

6 P. Leupen, Gods stad op aarde - Eenheid van Kerk en Staat in het eerste millennium na Christus, Amsterdam 1996, p. 137.

7 Marsilius van Padus, Defensor Pacis, discourse 2, 4 (geciteerd via O. O’Donovan \& J. Lockwood O’Donovan, From Irenaeus to Grotius - A Sourcebook in Christian Political Thought, Grand Rapids (VS)/Cambridge (VK) 1999, p. 437). 
'Daraus mercke, wilch rasende leute wyr sind so lange zeyt gewesen, die wyr die Türcken mit dem schwerd, die ketzer mit dem fewr, die Juden mit tödten haben wollen zum glauben zwingen, und das unkraut aus rotten mit unser eygen gewallt, gerade als weren wyr die leute, die uber hertzen und geyster regieren kündten (...).8

In 1544 doet hij dat nogmaals:

'Als wolt er [= Christus] sagen: Lassets doch also gehen, Ir solts nicht mit dem Schwert richten, Gehet jr nur fort mit dem Wort und prediget getrost wider die Ketzer und Rotten.' ${ }^{9}$

Dit betekent niet dat Luther volledige gelijkberechtiging in geloofszaken bepleitte. Een afwijkend geloof moest in de privésfeer geduld worden, maar de publieke verkondiging ervan niet, want dat zou de politiek-maatschappelijke orde in gevaar brengen. In het laatste geval sloot hij de doodstraf niet uit, met een beroep op Romeinen 13:2. ${ }^{10}$ De regel 'cuius regio eius religio' ('de godsdienst van de vorst bepaalt de godsdienst van de bevolking van zijn gebied') van de rijksdag van Augsburg (1555) sloot hierbij aan.

Bij Calvijn is een verwijzing naar de Bijbelse gelijkenis van het onkruid in de akker in dit verband niet te vinden. Hij verwacht dat de burgerlijke overheid ervoor zorgt dat de ware religie, die in Gods wet vervat is, niet openlijk en door openbare heiligschennis ongestraft geschonden en bezoedeld wordt. ${ }^{11}$ Bij de behandeling van Johannes 18:36 wijst hij weliswaar gewetensdwang af, maar tegelijk noemt hij het dwaas en onverstandig te besluiten dat de leer van het Evangelie en de zuivere godsdienst niet met de wapenen moeten worden verdedigd. Ketters moeten worden gestraft en de gewetens zijn slechts vrij zolang men met zijn opvatting niet in de openbaarheid treedt. De oude gereformeerden kunnen dus moeilijk als de grote kampioenen van de vrijheid van geweten en religie worden geprezen. ${ }^{12}$ Het was juist de eenstemmige overtuiging van Calvijn en zijn volgelingen dat de tussenkomst van de overheid in de zaak van de religie vereist was. ${ }^{13}$ Pleidooien voor politieke verdraagzaamheid waren in die tijd eerder bij humanisten te vinden.

Discussies onder calvinisten gingen in die tijd meer over de vraag of en wanneer je in verzet mocht komen tegen een overheid die de ware religie onderdrukte. Wanneer een overheid de Reformatie afwees, was dat voor Calvijn geen reden om die Reformatie met geweld af te dwingen. In dat geval achtte hij een voorlopige reli-

8 WA 17 II, S. 125, Z. 12-16, geciteerd via Klueting 2004, p. 62.

9 WA 52, S. 836, Z. 29f, geciteerd via Klueting 2004, p. 63. We beluisteren hier ook een verwijzing naar Matteüs 26:52 en Johannes 18:11, waar Jezus Petrus verbiedt hem met het zwaard te verdedigen.

10 Klueting 2004, p. 64.

$11 \mathrm{~J}$. Calvijn, Institutio religionis christianae $I V, x \times 3$.

12 D.J. de Groot, De Reformatie en de staatkunde, Franeker 1955, p. 171-173.

13 A. Kuyper, Het Calvinisme - zes Stone-lezingen, Barneveld 2008, p. 109. 
gievrede aanvaardbaar totdat de overheid tot het juiste inzicht zou zijn gekomen. ${ }^{14}$ Maar wanneer de rust was weergekeerd en de orde hersteld, zou een christelijke staat niet tolerant kunnen blijven. ${ }^{15}$

Calvijns leerling en opvolger Theodorus Beza (1519-1605) noemde het idee dat in een staat verschillende kerkgemeenschappen naast elkaar getolereerd zouden moeten worden, zelfs een duivels leerstuk. In een brief uit 1566 aan de hugenootse predikant Jean Taffin in Metz stelde hij dat die gedachte voortkomt uit de denkwereld van de humanist Castellio. Vervolging achtte hij verkieslijker dan vrijheid voor allen, want die vrijheid leidt tot indifferentisme. Het is beter te lijden en te sterven dan aan iedere opvatting vrijheid te geven. ${ }^{16}$ Maar later zou hij van mening veranderen.

In 1578 werd Jan van Nassau, broer van Willem van Oranje, stadhouder van Gelre. Bij zijn ambtsaanvaarding beloofde hij, zelf lutheraan, de rooms-katholieke eredienst ongemoeid te laten. Maar al snel merkte hij dat de Reformatie sterk opkwam in Gelre. Liefst zou hij die met zijn politieke macht steunen. Maar zijn belofte aan de rooms-katholieken ... Of is een belofte aan ketters niet bindend? Hij schreef toen brieven met een vraag om advies aan onder anderen Beza. Deze antwoordde hem dat het verkeerd is het kwade te doen (een belofte breken) opdat het goede eruit voortkome (vergelijk Romeinen 3:8). De beste weg om het Evangelie te verbreiden ligt niet in wapengeweld, maar in de eenvoudige prediking daarvan en in betoon van christelijke liefde. Aan gedwongen aanvaarding van de waarheid is niet de minste betekenis te hechten.

Beza heeft geen motivering gegeven voor deze omslag; Van Schelven denkt dat hij besefte dat dit beleid praktisch onvermijdelijk was geworden. ${ }^{17}$ Het is ook mogelijk dat hij onder de indruk was van een brief van De Villiers, hofprediker van Willem van Oranje, waarin deze de politiek van Oranje toelichtte om te voorkomen dat Beza de zijde van diens tegenstander Petrus Datheen zou kiezen. ${ }^{18}$ Een principiële fundering van de tolerantie vinden we hier nog niet.

Overigens werd in Genève zelf pas in 1680, onder invloed van internationale staatkundige verhoudingen, vrijheid van godsdienst ingevoerd. ${ }^{19}$

14 H. Klink, Opstand, politiek en religie bij Willem van Oranje. Een thematische biografie, Heerenveen 1997, p. 327.

15 S. Paas, Vrede stichten - Politieke meditaties, Zoetermeer 2007, p. 401.

16 Beza aan Taffin: Het is beter 'souffrir mille mortes que de consentir a une telle et si malheureuse liberté', C. Boer, Hofpredikers van Prins Willem van Oranje - Jean Taffin en Pierre L'Oyseleur de Villiers (Kerkhistorische Studiën, deel V), Den Haag 1952, p. 23. A.A. van Schelven,. Het Calvinisme gedurende zijn bloeitijd I: Genève - Frankrijk, Amsterdam 1943, p. 86 e.v.; A.A. van Schelven, Uit den strijd der geesten, Amsterdam 1944, p. 38.

17 Van Schelven 1943, p. 87; Van Schelven 1944, p. 67.

18 A. Dufour, Théodore de Bèze - Poète et theologien, Genève 2006, p. 167.

19 Van Schelven 1943, p. 112. 


\section{De hugenoten en gereformeerden elders}

In Frankrijk vormden de aanhangers van de Reformatie, hugenoten genoemd, een minderheid. Ze kregen te maken met een koning die godsdienstige verdeeldheid schadelijk achtte voor zijn land. Voor hem gold: 'un roi, une loy, une foy'. ${ }^{20}$ Toch was hun eerste aandrang niet voor tolerantie te pleiten. François de Morel, predikant in Parijs en voorzitter van de eerste synode in Parijs in 1559, noemde in een brief aan Calvijn een verbod op het doden van ketters en een bevel tot tolerantie onbijbels. Het huidige martelaarschap was in zijn ogen verkieslijker dan het accepteren van de leugen als waarheid. De juiste weg was een serieus theologisch debat tussen de verschillende partijen. ${ }^{21}$ Als de koning de godsdienstige geschilpunten die tot de breuk met Rome geleid hadden, serieus zou onderzoeken, zou hij wel tot de conclusie komen dat Reformatie van de Kerk noodzakelijk was. ${ }^{22}$ In afwachting daarvan zouden de vervolgingen uiteraard gestaakt moeten worden.

In 1560 drong Gaspard de Coligny namens de hugenoten in een brief aan de koning aan op een nationaal concilie dat de principiële vragen zou moeten beslechten. Hun verwachting was dat de waarheid der Schriften in een disputatie, als in een intellectuele wedstrijd, de tegenpartij zou overtuigen. Maar dit voorstel werd door de Franse Staten-Generaal afgewezen. ${ }^{23}$

In de loop van dat decennium en vooral na de Bartholomeusnacht (1572) begon tot de Franse gereformeerden door te dringen dat ze dit doel niet zouden bereiken. Sindsdien verklaarden zij zich bereid genoegen te nemen met een bescheiden eigen plaats in een voornamelijk rooms-katholieke samenleving. In ruil voor een zekere mate van godsdienstvrijheid wilden zij een minderheidspositie in het kerkelijk en politiek leven van de Franse samenleving aanvaarden. ${ }^{24}$ Ze voerden nu aan dat een gedwongen geloofskeuze geen betekenis heeft, dat vervolging het land politieke en economische schade toebrengt en dat verscheidenheid van religie geen gevaar oplevert voor de openbare orde. Ook wezen ze op de raad van de Farizeeër Gamaliël in Handelingen 5:38-39: Laat de toekomst uitwijzen of de Reformatie uit God is of niet. ${ }^{25}$ Deze argumenten voor tolerantie zijn meer natuurrechtelijk of politiek dan Bijbels gefundeerd.

Een belangrijk pleitbezorger voor tolerantie was in die tijd de Zwitserse predikant Pierre Viret (1511-1571), die vanaf 1561 in Frankrijk werkzaam was. In zijn boek

20 J.N. Bakhuizen van den Brink, Protestantse Pleidooien II, Kampen 1962, p. 9; H. Lademacher, 'Freiheit - Religion - Gewissen. Die Grenzen der religiösen Toleranz in der Republik', in: H. Lademacher e.a. (red.), Ablehung - Duldung - Anerkennung, Toleranz in den Niederlanden und in Deutschland. Ein historischer und aktueller Vergleich, Münster/New York/München/Berlijn 2004, p. 118: 'Es ging um die ganz simple Frage, ob ein Untertan, der nicht das Bekenntnis seiner ihm vorgesetzten Obrigkeit habe, ein loyaler Untertan sein könnte.'

21 H.A. Speelman, Calvijn en de zelfstandigheid van de kerk, Kampen 1994, p. 142.

22 Zie bijv. de Apologie van de kerk te Parijs tot het Franse volk (1557), Bakhuizen van den Brink 1962, p. 46-58.

23 Speelman 1994, p. 161, 169, 174.

24 Speelman 1994, p. 163.

25 Van Schelven 1944, p. 42. 
L'interim, fait par dialogues (1565) gaf hij nauwkeurig aan waar de mogelijkheden tot en grenzen van tolerantie ten opzichte van een andere godsdienstige stroming lagen. Tolerantie uit onverschilligheid wees hij af, maar hij bepleitte een tolerantie als praktische regeling om samen te leven zonder de verschillen toe te dekken. Daarmee wordt een burgeroorlog voorkomen, de echte christenen worden niet vervolgd en er vindt geen gewetensdwang plaats. Dit laatste is uit den boze, omdat geloof nooit kan worden afgedwongen: dwang kweekt slechts huichelaars. De mensen moeten door overtuiging, door middel van de leer, door het goede voorbeeld en door gebed gewonnen worden voor de waarheid van het Evangelie.

Weliswaar deelde hij de overtuiging van Calvijn en Beza ten aanzien van de taak van de overheid op het gebied van de religie, maar dat rechtvaardigde voor hem niet het gebruik van alle middelen. Anders dan zij wees hij geweld in religiezaken principieel af. Hij beriep zich daarvoor op de gelijkenis van het onkruid in de akker. $^{26}$

Elders in Europa werd dit al in praktijk gebracht. Zo sprak in Hongarije de gereformeerde synode van Torda (1564) zich uit voor publieke tolerantie. In 1606 werd dit in een rijkswet vastgelegd. Voor die tijd was dat zeer ongewoon. Van Schelven ziet daarin invloed van de Turken: de volgelingen van de profeet van Mekka, die tot Hongarije waren opgerukt, lieten destijds ieder vrij in zijn overtuiging. Dit voorbeeld werkte toen aanstekelijk. Zo werd Hongarije asielland voor anti-trinitariërs. ${ }^{27}$ In Zevenburgen (het huidige Hongaarstalige deel van Roemenië) kwam sinds 1571 vrijheid voor vier religies, met tolerantie voor anderen. ${ }^{28}$

Over de ontwikkelingen in de Lage Landen gaat de volgende paragraaf.

\section{Predikanten in de omgeving van Willem van Oranje}

Er zijn goede redenen om in dit artikel de schijnwerper te richten op de Lage Landen. Prins Willem van Oranje, de leider van de opstand tegen Spanje, heeft immers meer dan wie ook in zijn tijd geijverd voor het in vrede naast elkaar leven van katholieken en protestanten.

Vooraf een korte schets van de historische situatie.

In 1555 had Karel V de soevereiniteit over de Nederlandse gewesten overgedragen van zijn zoon Filips II. Deze vertrok in 1559 definitief naar Spanje, waar hij zijn vader als koning was opgevolgd, en benoemde zijn halfzuster Margaretha van Parma als landvoogdes in de Nederlanden. Onder haar had elk van de gewesten mauuaises'. Zie H. Klink, Opstand, politiek en religie bij Willem van Oranje. Een thematische biografie, Heerenveen 1997, p. 71 e.v.; Paas 2007, p. 396 e.v.

27 A.A. van Schelven, Het Calvinisme gedurende zijn bloeitijd III: Polen - Bohemen - Hongarije en Zevenburgen, Amsterdam 1965, p. 141 e.v. Anti-trinitariërs ontkennen het God-zijn van Jezus en de Heilige Geest en daarmee de Drie-eenheid van God. Klueting 2004, p. 56. 
een stadhouder. Een van hen was Willem van Nassau, tevens soeverein vorst van het prinsdom Orange. Hij was ook Eerste Edele van Brabant en lid van de Raad van State, het hoogste adviescollege van de landvoogdes.

In opdracht van Filips II werd de reformatorische beweging zwaar vervolgd. Als protest daartegen bood de lagere adel, onder aanvoering van onder anderen Lodewijk van Nassau, broer van Willem, in 1566 aan de landvoogdes een Smeekschrift aan voor verzachting van de maatregelen. In die zomer begonnen de gereformeerden met openluchtdiensten buiten de Vlaamse steden (hagenpreken), gevolgd door de vernietiging van beelden in de kerken. Om de onrust de beteugelen stuurde Filips in 1567 de hertog van Alva naar de Nederlanden. Willem van Oranje week uit naar Duitsland en bracht daar troepen bijeen om de Nederlanden te bevrijden. In 1568 mislukten (na een aanvankelijk succes bij Heiligerlee) twee veldtochten, in het noorden en langs de Maas. In 1572 wisten de Watergeuzen onverwachts Den Briel in te nemen, waarna meer steden in Holland en Zeeland de kant van de prins kozen. Nog datzelfde jaar kwamen in Dordrecht de Hollandse steden bijeen voor de eerste vrije vergadering van de Staten van Holland. Prins Willem verhuisde in 1573 naar Delft (zijn thuisstad Breda was nog in Spaanse handen) en voegde zich daar bij de gereformeerde kerk.

Hij trachtte de Nederlanden weer te verenigen en bracht daartoe in 1576 de Pacificatie van Gent tot stand. Deze gewesten stelden de Oostenrijkse aartshertog Matthias als hun landvoogd aan tegenover de Spaanse landvoogd Don Juan. Maar dit verbond viel al in 1579 uiteen: de zuidelijke gewesten sloten zich aaneen in de Unie van Atrecht (de huidige Franse stad Arras) onder het Spaanse gezag, en de noordelijke als vrije gewesten in de Unie van Utrecht, waarin voor het eerst het beginsel van gewetensvrijheid publiek werd erkend (artikel XIII). Een jaar later viel Groningen weg uit de Unie doordat stadhouder Rennenberg overliep naar Spaanse zijde. Dat heeft het vertrouwen in de rooms-katholieke medeburgers ernstig geschaad. In 1581 besloten de gewesten die in deze Unie verenigd waren, Filips II als hun soeverein af te zweren, waarna de basis werd gelegd voor de Republiek, die in 1588 werd uitgeroepen.

Omdat het ons in dit artikel vooral te doen is om de vraag of er Bijbelse argumenten waren voor de keus voor publieke tolerantie, kijken we eerst naar de predikanten in de omgeving van Willem van Oranje. Dan gaat het met name om Jean Taffin, Pierre Loyseleur de Villiers en Franciscus Junius.

Jean Taffin (1529-1602) ${ }^{29}$ kwam in 1573 uit Heidelberg, waar hij een Franse vluchtelingengemeente leidde, om zich in dienst van de prins te stellen. Hij leidde de bevestiging van diens huwelijk met Charlotte de Bourbon in 1575 in Den Briel. Zoals hierna blijkt, werkte hij nauw samen met Pierre Loyseleur de Villiers (circa 1530-1590). 
Deze predikant was na de Bartholomeusnacht (1572) naar Londen gevlucht, waar hij een Franse vluchtelingengemeente diende. Een benoeming als hoogleraar in Leiden in 1575 wees hij af, maar twee jaar later kwam hij wel naar de Nederlanden om hofprediker van prins Willem te worden. Hij verdedigde de godsdienstpolitiek van de prins en had een belangrijk aandeel in de opstelling van diens Apologie (1581). Hij voltrok het huwelijk van de prins met Louise de Coligny (1583). De Villiers had een afkeer van geweld. Geweld was voor hem geen bruikbaar middel om de wereld van haar dwaalwegen terug te brengen, om mensen te bekeren en problemen op te lossen. Hij en ook de prins zijn wel van religieus opportunisme beschuldigd, maar uit stellingen die De Villiers publiceerde over de kerk (onder andere over de verhouding van de roomse tot de reformatorische kerken - naar zijn mening waren in de Rooms-Katholieke Kerk de sporen van kerk en sacramenten niet geheel verloren), blijkt dat dit verwijt geen steek houdt. De door hem voorgestane tolerantie houdt wel degelijk verband met zijn dogmatisch inzicht. ${ }^{30}$

In 1578 stelden Taffin en De Villiers, met nog twee collega's, in opdracht van de synode van Dordrecht een rekest op, gericht aan de toenmalige (door de StatenGeneraal van de opstandige gewesten aangestelde) landvoogd aartshertog Matthias en de Raad van State. Daarin werd gevraagd om een vrije uitoefening van de godsdienst voor protestanten en rooms-katholieken. Tegelijk werd afstand genomen van geweld tegen rooms-katholieken. Het rekest wijst erop dat door vervolgingen niets bereikt wordt en dat de protestanten juist veel voor het vaderland hebben gedaan. De godsdienstige verschillen van het volk spelen enkel de vijand, Don Juan, de landvoogd namens de koning van Spanje, in de kaart. Bovendien moet de regering bedenken dat een land waarin aan beide religies openbare godsdienstoefening is toegestaan, te verkiezen is boven een land waarin velen 'eeuwichlijck blijven zonder Religie'. ${ }^{31}$

Een jaar later ontvingen zij beiden, samen met Marnix van Sint-Aldegonde, een verzoek om advies van graaf Jan van Nassau, toen stadhouder van Gelre, over het tolereren van de rooms-katholieke godsdienstoefening, zoals ook Beza had ontvangen. De Villiers c.s. antwoordden dat Jan zijn belofte van bescherming van de rooms-katholieke inwoners moest houden. Hij hoefde zich niet bezwaard te voelen om het tolereren van bijgeloof. Zoals Abraham er geen bezwaar tegen had met heidense vorsten als bondgenoten samen te werken en Jozef hand in hand ging met de Egyptenaren, is het hier temeer geoorloofd, waar het niet om heidenen maar om afgedwaalde christenen gaat. Uitoefening van dwang zal de roomskatholieken eerder afkerig maken van alle godsdienst dan hen te winnen voor de gereformeerde religie. ${ }^{32}$

Een derde predikant in de kring rondom Willem van Oranje was Franciscus Junius (1545-1602). ${ }^{33}$ Deze schreef als 20-jarige predikant van de Waalse 
gemeente in Antwerpen (1565) een open brief aan koning Filips II, waarin hij betoogde dat onenigheid inzake de godsdienst alleen kon worden beslecht door hoor en wederhoor in vrijheid, waarbij het Woord van God de maatstaf moest zijn. Hij koos in dit geschrift ${ }^{34}$ geen positie ten aanzien van de waarheidsvraag als zodanig tussen katholicisme en hervorming, al was zijn standpunt duidelijk gereformeerd, maar wees op praktische en economische gezichtspunten. Eenheid in geloof laat zich niet door geweld afdwingen, want godsdienst en geloof zijn een zaak van het hart. Lichamelijke straf helpt niet tegen diepe overtuigingen. Dat er twee godsdiensten in één staat getolereerd worden, is dan ook niet nieuw. In de hele wereldgeschiedenis is dit eenheidsideaal niet bereikt. Christus riep niet op het zwaard te hanteren voor het geloof. Bij openbare uitoefening zal de waarheid de leugen aan het licht brengen. De koning kan beter bedenken dat wie trouw is in de dienst aan God, ook de koning het trouwst zal dienen. Het typisch 'politieke' argument van het belang van de staat vormde een belangrijk element in het geschrift van Junius. ${ }^{35}$

Dit geschrift werd onder andere verspreid op de rijksdag van Augsburg (1566) als ondersteuning van het pleidooi om ook de calvinisten te laten delen in de godsdienstvrede van Augsburg (1555).

Junius was betrokken bij het Smeekschrift dat de edelen in 1566 aanboden aan landvoogdes Margaretha. Toen de edelen in het huis van de graaf van Culemborg in Brussel bijeen waren om dat stuk op te stellen, leidde hij daar een godsdienstoefening. ${ }^{36}$ Hij hield hagenpreken in West-Vlaanderen, maar keurde de beeldenstorm af. In 1568 was hij veldprediker bij de troepen van de prins. Daarna werd hij hoogleraar, achtereenvolgens in Neustadt, in Heidelberg en in Leiden.

In dit verband valt ook nog te wijzen op Gilles le Clercq (circa 1530-na 1569), een calvinistisch jurist die in mei 1566 commentaar gaf op het Smeekschrift van de edelen. Hij betoogde dat de oudtestamentische wetten van Deuteronomium 13 (de doodstraf op afgoderij en valse profetie) na de komst van Christus niet meer geldig waren. Ketterij is geen majesteitsschennis. Men moet ketters met zachtmoedigheid tot het ware geloof brengen en er dient ruimte te zijn voor wie te goeder trouw dwaalt. ${ }^{37}$

Niet alle gereformeerde predikanten in de Nederlanden dachten overigens zo. Petrus Datheen (1531/1532-1588) was tegenstander van de godsdienstpolitiek van de prins. Hij kon zich niet voorstellen dat een christelijke overheid bereid en gerechtigd kan zijn om de (roomse) afgoderij weer in te stellen. ${ }^{38}$

34 Brief Discours envoyé au Roy Philippe nostre sire et souverain seigneur, pour le bien et profit de sa Majesté, et singuliérement de ses pays bas (enz.).

35 Van Schelven 1944, p. 27; Bakhuizen van den Brink 1962, p. 170. Klink 1997, p. 200 e.v.

36 R.H. Bremmer, Van Opstand tot Koninkrijk - Hoogtepunten uit onze geschiedenis en geschiedschrijving, Amsterdam 1969, p. 18.

37 Klink 1997, p. 193 e.v.

38 Boer 1952, p. 103. 


\section{De Prins van Oranje en zijn broer Lodewijk van Nassau}

Willem van Oranje groeide op als oudste zoon in het kinderrijke gezin van Willem de Rijke en Juliana van Stolberg op de Dillenburg in Duitsland. Hij kreeg daar een lutherse opvoeding. Maar als elfjarige verhuisde hij naar Brussel, waar hij aan het hof van Karel V in rooms-katholieke geest zou worden opgevoed. Dat had de keizer als voorwaarde gesteld voor het aanvaarden van de erfenis van Willems jonggestorven neef Reynaert van Nassau, waaronder het soevereine prinsdom Orange. Vanwege het dynastieke belang hadden Willems ouders daarin bewilligd.

Het grafelijke huis van Nassau bestond uit een Duitse en een Nederlandse tak. Willem de Rijke (1487-1559) bestuurde vanaf de Dillenburg de Duitse erflanden, zijn oudere broer Hendrik III (1483-1538) vanaf het Kasteel van Breda de Nederlandse. Hendrik was getrouwd met Claudia de Châlon (1498-1521) en had één zoon, Reynaert van Nassau (1519-1544), naar zijn moeder ook wel René de Châlon genoemd. Deze familie was rooms-katholiek, de familie op de Dillenburg luthers. Willem de Rijke had vijf zonen, waarvan de oudste eveneens Willem heette.

Reynaert erfde in 1530 van zijn oom Filibert de Châlon het prinsdom Orange, dat daardoor in het huis Nassau kwam. In 1538 erfde hij ook de goederen van zijn vader, inclusief het stadhouderschap namens Karel V over Holland, Zeeland en Utrecht. In 1543 kreeg hij Gelre daar nog bij. Een jaar later sneuvelde hij in dienst van Karel V bij het beleg van Saint-Dizier. Omdat hij geen kinderen had, had hij zijn neef Willem als enig erfgenaam benoemd. Deze werd daardoor de Eerste Edele van Brabant. Maar Karel V wilde niet dat zo'n belangrijke positie in de Lage Landen in lutherse handen kwam.

In die tijd werden in de Nederlanden de protestanten met harde hand vervolgd. Het waren aanvankelijk vooral humanitaire motieven waardoor dit de prins tegen de borst stuitte. In zijn Apologie schreef Willem van Oranje over een gesprek dat hij had met de Franse koning Hendrik II in 1559 in het bos van Vincennes: 'Ik wil gaarne toegeven dat ik toen een grote mate van medelijden voelde met zo vele mensen van eer die aan de dood overgeleverd waren.' Zijn familiebanden met lutherse vorsten in Duitsland zullen daarbij ook meegespeeld hebben. In een gesprek met landvoogdes Margaretha van Parma (1561) prees hij de hertog van Kleef om zijn religiepolitiek, waarin deze ruimte schiep voor de protestantse en de rooms-katholieke godsdienst. Hierin herkennen we al zijn eigen ideaal. ${ }^{39}$

Op 31 december 1564 sprak de Raad van State over de instructie die aan de graaf van Egmond zou worden meegegeven voor zijn bezoek aan Filips II in Madrid. Oranje hield daarbij een lange rede, waarvan slechts een samenvatting bekend is. Hij wees erop dat in alle omringende landen de godsdienst doelwit is van verandering en inzet van strijd. Hoe zou men dan alleen hier de oude religie met plakkaten en inquisitie kunnen redden, en dat nog wel bij het slechte leven van de gees- 
telijkheid? Vervolgens hield hij een openlijk pleidooi voor tolerantie met de woorden: 'Hoezeer ik aan het katholieke geloof gehecht ben, ik kan niet goedkeuren dat vorsten over het geweten van hun onderdanen willen heersen en hun de vrijheid van geloof en godsdienst ontnemen. ${ }^{40}$

Van Deursen tekent hierbij aan: 'Zijn woorden waren die van een erasmiaan. Hij beriep zich niet op de Bijbel, maar op zijn eigen oordeel (...) Zijn motivering van de tolerantie is meer in het humanisme dan in de christelijke religie zelf geworteld.' 41

Willem bekende al meer kleur in 1568 in een brief aan de koning van Denemarken, waarin hij schreef: 'Filips wil de leer van het evangelie onderdrukken en haar belijders ter dood brengen.' Voordien ging het Oranje om de slachtoffers. Hij nam het voor hen op, maar deelde hun geloof niet. Nu zei hij nadrukkelijk: Filips richt zich tegen het evangelie zelf. ${ }^{42}$ Dat hield een duidelijke keus voor de Reformatie in.

Bijbelse argumenten voor tolerantie jegens andersdenkenden vinden we hij hem dan niet, of het moet zijn een zinspeling op de raad van Gamaliël dat de toekomstige ontwikkeling wel zal uitwijzen wat uit God is en wat niet. In zijn Mémoire sur l'état critique des Pays-Bas et les moyens d'y poser remède (november 1566) schreef hij dat het zeker is dat geen sekte of afwijkende geloofsovertuiging duurzaam kan zijn, zoals het voorbeeld van de sekte van Arius en andere dwaalleren ons voor ogen houdt: hoewel deze veroordeeld en als schadelijk afgewezen werden, onderwierp men ze desondanks niet aan de dwang van geweld, om grotere schade te vermijden. Maar nadat ze lang stand hadden gehouden, werden ze uiteindelijk, omdat ze niet van God kwamen, overwonnen en opgeheven door de ijver, zorg, plichtsbetrachting en goede leer van geleerde manen en deskundigen in de Heilige Schrift, zonder andere kracht en met grote versterking van de ware christelijke religie. Dat zou de koning moeten navolgen. ${ }^{43}$

Over onkruid spreekt hij juist andersom dan in de Bijbelse gelijkenis: In een brief d.d. 31 augustus 1566 aan Duitse vorsten pleitte de Prins van Oranje voor maatregelen die scheuringen tussen luthersen en gereformeerden zouden voorkomen

40 A.Th. van Deursen, 'Willem van Oranje', in: A.Th. van Deursen \& H. de Schepper, Willem van Oranje - een strijd voor vrijheid en verdraagzaamheid, Weesp/Tielt 1984, p. 116.

41 Van Deursen 1984, p. 117.

42 Van Deursen 1984, p. 125.

43 Mémoire sur l'état critique des Pays-Bas et les moyens d'y poser remède, in: Archives ou Correspondance inédite de la Maison d'Orange-Nassau, red. Groen van Prinsterer, Ie série, tome 2, Leiden 1835, p. 430-445; het citaat op p. 442: 'Puisqu'il est certaine que nulle secte, ny opinion sinistre peult estre de durée, ayant mesmement l'exemple de la secte d'Arius et aultres erreurs devant les yeux: lesquelles, oires qu'elles estiont condamnés et rejectées pous méchantes, si ne furent ellés pas toutes fois contraintes par force, pour éviter plus grand inconvenient; ains pour n'estre de Dieu, après avoir bien durées, ont esté supprimées à la fin et abolies par la diligence, soing, debvoir et bonne doctrine des gens scavans et experts aux escriptures sainctes, sans aultre force et avecques très grande corrobération de la vraye religion chrestienne.' 
en ervoor zouden zorgen dat het rechte Woord van God geplant en het onkruid uitgeroeid zal worden. ${ }^{44}$

Dat ligt anders bij zijn broer Lodewijk. Deze schreef in een brief d.d. 15 februari 1567 aan keurvorst August van Saksen, die niets van calvinisten moest hebben: Het is beter het calvinisme te verdragen en - overeenkomstig de Bijbelse gelijkenis - het onkruid te laten groeien tot de tijd van de oogst. ${ }^{45}$ Lodewijk was geen calvinist, maar lutheraan. Samen met Jan van Toulouse en Nicolaas de Hames, die beiden calvinistisch gezind waren, speelde hij een leidende rol in het Verbond der Edelen, dat - zoals hiervoor al genoemd - in 1566 een Smeekschrift aan de landvoogdes aanbood met een pleidooi voor tolerantie.

In 1572 kwamen de eerste successen in de vrijheidsstrijd tegen Spanje. In de loop van dat jaar kwam de eerste vrije vergadering van de staten van Holland in Dordrecht bijeen. Marnix van Sint-Aldegonde vertegenwoordigde daar de prins. Op zijn advies werd besloten:

'gehouden zal worden vrijheyt der religien, zoo wel der gereformeerde als der roomsche religie, ende dat een yegelick in den zijnen in 't openbaar ende in eenige kercken of te capellen (zoo dat gevouchelicste bij de Overichheyt zal geordineert worden) zal gebruycken vrije exercitie der zelven, zonder dat daer inne yemant empechement, hinder ofte moeijenisse gedaen zal worden ende dat de geestelicke personen haeren staet ende onbecommert-blijven zullen. ${ }^{46}$

Willem van Oranje onderscheidde zich in die zin van zijn tijdgenoten dat hij met gelijke kracht opkwam voor vrijheid van katholieken, ${ }^{47}$ protestanten en doopsgezinden, zowel toen hij nog formeel katholiek was ${ }^{48}$ als nadat hij in 1573 was overgegaan naar de Gereformeerde Kerk. Pas na het verraad van Rennenberg in 1580 werd zijn houding jegens de katholieken negatiever. Dat had een politieke grond: hun onbetrouwbaarheid in de strijd tegen Spanje.

Klink 1997, p. 234.

'Weil dan die Calvinisten dem Pabst solchen abbruch thun, und uns weit neher seien als die Papisten, musz man sie dulden, und das unkraut wachsen lassen, bis zur zeit der ernde.' Archives ou Correspondance inédite de la Maison d'Orange-Nassau, red. Groen van Prinsterer, Ie série, supplement, Leiden 1847, p. 56.

H. de Wilde, Om de vrijheid, Kampen 1927, p. 16.

'Steeds heeft Willem I regt en billijkheid ook jegens de Roomschen gewild, uit staatkunde en uit pligtsbesef. Nauwgezet in het nakomen van zijn eed, heeft hij nooit toegelaten dat iemand eenig leed of ongelijk zou geschieden; altijd voor oogen houdende dat God regtvaardig is en geen valschen eed ongestraft laat.' G. Groen van Prinsterer, Handboek der Geschiedenis van het Vaderland, Amsterdam 1872, par. 185.

48 Klink 1997, p. 148: 'Wanneer Oranje in 1566 [beeldenstorm] bereid is de katholieken bescherming te bieden, hoeft dat niet per definitie te betekenen dat hij de katholieke religie daadwerkelijk aanhangt. (...) Oranje werd hierin gedreven door politieke motieven en door het gevoel van billijkheid. Hij ijverde er in deze tijd juist voor dat ook de protestanten vrijheid van godsdienst vergund zou worden, naast de rooms-katholieke religie.' 
Zijn motieven waren deels politiek, deels humanitair van aard. Hij zag in dat alleen door eendracht van alle Nederlanders de koning van Spanje kon worden verslagen. Tolerantie was ook de enige weg om onlusten en bloedvergieten te voorkomen. Ook was hij ervan overtuigd dat een vorst niet mocht heersen over de gewetens van zijn onderdanen. Zijn pleidooi voor tolerantie kwam niet voort uit religieuze onverschilligheid, maar uit besef van grenzen aan de overheidsmacht. ${ }^{49}$

Over de wortels van deze visie wordt verschillend gedacht. Ik haalde hiervoor Van Deursen al aan: 'Zijn woorden waren die van een erasmiaan', meer in het humanisme dan in de Bijbel geworteld. Aalders typeert zijn positie als meer luthers dan calvinistisch. 'Het overheersende motief van zijn leven en werk was immers het beginsel van de gewetensvrijheid, en op grond daarvan de staatsrechtelijke erkenning van de godsdienstvrijheid der burgers. Dat was oer-Luthers.' Volgens Aalders komt Oranjes streven om aan allen volkomen vrijheid van godsdienst te geven voort uit het besef dat het geestelijke en het wereldlijke regiment nadrukkelijk onderscheiden dienen te worden. Daarbij kwam de overtuiging dat een staatsbestel waarin vorst en volk beide de hun van Godswege toegekende plaats kennen en in onderlinge samenwerking het land besturen, de meest beloftevolle staatsvorm is. 'Dat alles was zuiver erfgoed van Luther!'50

Klink is het met geen van beide typeringen eens. De tolerante inslag die Oranje kenmerkt, is naar zijn oordeel niet per definitie erasmiaans van aard. Het feit dat hij meer dan eens een pleidooi hield voor gewetensvrijheid en verschillende vormen van religievrijheid, hangt volgens Klink nauw samen met zijn eigen karakter, dat zich niet verenigen kon met religiedwang. Ook staatsmanswijsheid drong hem daartoe. Bovendien vond hij aansluiting bij een authentiek protestantse stroming waarbinnen ook tolerant gedacht werd. Gewetensdwang was er uit den boze. In 1563 deed de lutheraan Philips van Hessen aan Oranje het voorstel om in zijn vorstendom Orange een vorm van religievrede in te voeren, waardoor katholiek en protestant vreedzaam naast elkaar konden wonen. Ook de modus vivendi tusen rooms-katholieken en protestanten in het Duitse Rijk diende volgens Klink de prins als voorbeeld. Zelfs binnen het calvinisme waren stemmen te horen die pleitten voor een vreedzame houding ten opzichte van hen die de 'andere' religie aanhingen. Klink wijst op de nauwe medewerker van Calvijn, Viret, en ook op de Franse admiraal Gaspard de Coligny, voorman van de hugenoten, en op Junius, veldprediker in Oranjes troepen,. Vanuit evangelische en pastorale motieven bepleitten zij een gematigde koers voor regering en Kerk ten opzichte van de rooms-katholieken. ${ }^{51}$

49 J.W. Sap, Wegbereiders der revolutie. Calvinisme en de strijd om de democratische rechtsstaat, Groningen 1993, p. 110.

50 W. Aalders, Luther en de angst van het westen - Een pleidooi voor de rechtsstaat, Den Haag 1982, p. 116, 118.

51 Klink 1997, p. 331. 
Het komt ons voor dat een persoon als de Prins van Oranje, die zo'n uitgebreid netwerk van contacten onderhield, zowel met Duitse vorsten als met Franse hugenoten, van diverse kanten beïnvloed zal zijn in zijn denken. Het is dus niet nodig hier een keus te maken en de prins rechtlijnig bij een van de toenmalige stromingen in te delen. Wel is duidelijk dat Bijbelse argumenten bij hem niet of nauwelijks een rol speelden.

Het beroep op de gelijkenis van het onkruid in de akker was in die tijd bij gereformeerden zelfs enigszins verdacht, omdat humanisten ${ }^{52}$ en doopsgezinden er gebruik van maakten. De Antwerpse doopsgezinden stuurden in 1566 een rekest aan de prins, waarin zij om vrijheid vroegen met een beroep op deze gelijkenis, het woord van Jezus dat er altijd tweedracht zal zijn (Matteüs 10:35) en de raad van Gamaliël. ${ }^{53}$ Van Schelven concludeert dat de gelijkenis van het onkruid in de akker dat samen met de tarwe moet opgroeien, in geen enkel ander verzoekschrift of uiteenzetting uit die tijd, voor zover hij weet, voorkwam, maar wel bij de humanist Castellio (1515-1563, tegenstander van Calvijn in Genève) en bij de erasmiaan Coornhert (1522-1590). ${ }^{54}$

Samenvattend kunnen we stellen dat de gedachte van godsdienstige en politieke verdraagzaamheid door de meeste calvinisten in de Lage Landen meer uit praktische overwegingen dan op grond van een diepe overtuiging is aangehangen en aanvaard. Ondanks de afschuw die de calvinist heeft van de roomse dwalingen, wil hij toch een regeling aanvaarden waarbij roomsen en hervormden vreedzaam samenleven binnen de muren van één stad. Zo'n regeling is namelijk te verkiezen boven de gruwelen van een burgeroorlog. Deze verdraagzaamheid staat ver af van een positieve waardering van de godsdienstige overtuiging van de tegenpartij; het gaat er enkel om elkaar met vrede te laten en te dulden. Dat is de onvermijdelijke consequentie voor wie ernst maakt met de gewetensvrijheid. De Prins van Oranje is hierin verder gegaan dan zijn raadgevers, doordat hij ook aan de dopers deze vrijheid wilde laten.

\section{Calvinisten omstreeks 1600}

Voor de gereformeerden in de periode na de dood van Willem van Oranje is de Duitse rechtsfilosoof Johannes Althusius (1557-1638) een goede representant. $\mathrm{Na}$ een hoogleraarschap in Herborn werd hij in 1604 bestuurder (syndicus) van de

52 Met 'humanisten' werden in die tijd christenen aangeduid die minder confessioneel gebonden wilden zijn dan calvinisten of lutheranen.

53 Willem van Oranje had hier nog niet op gereageerd toen hij in 1567 uitweek voor Alva. In de Statenvergadering van 1577 in Dordrecht bepleitte hij vrijheid voor doopsgezinden met verwijzing naar de gulden regel van Matteüs 7:12 (negatief geformuleerd). Dr. J.Th. de Visser, Kerk en Staat II, Leiden [1926], p. 433.

54 Van Schelven 1944, p. 31 e.v., 40, 49. Zo ook H. Lademacher, 'Freiheit - Religion - Gewissen. Die Grenzen der religiösen Toleranz in der Republik', in: H. Lademacher e.a. (red.), Ablehung - Duldung - Anerkennung, Toleranz in den Niederlanden und in Deutschland. Ein historischer und aktueller Vergleich, Münster/New York/München/Berlijn 2004, p. 128. 
stad Emden. Zijn opvattingen heeft hij uiteengezet in het boek Politica methodice digesta. Daarin betoogt hij dat de staat rust op twee verbonden: (1) tussen God, volk en vorst - de laatsten beloven de ware kennis en verering van God te verdedigen als antwoord op zijn belofte van zegen en bescherming, en (2) tussen vorst en volk(svertegenwoordigers): de vorst zal zich houden aan de gemaakte afspraken in ruil voor gehoorzaamheid.

Volgens de O’Donovans is er bij Althusius een erastiaanse tendens te bespeuren: het gezag van de overheid strekt zich ook uit over kerkelijke zaken. ${ }^{55}$ De vorst is volgens Althusius zelf wel gebonden aan de gehele decaloog. Deze is voor alle volken alleen in zoverre geldig als hij met de wet der natuur, die alle volken gemeenschappelijk hebben, overeenstemt en voor zover hij door Christus als hoogste Koning is herhaald. Bij deze beperking heeft Althusius mogelijk gedacht aan het sabbatsgebod.

De overheid heeft de taak de rechtzinnige godsdienst te onderwijzen en de goede eredienst in te stellen. In het verbond met het volk belooft zij de ware Godskennis in haar rijk te zullen verbreiden. Zo heeft immers God de kerk aan de zorg van de overheid toevertrouwd, omdat volk en overheid samen in het verbond staan. De overheid stelt het predikambt in en richt scholen op. Zij beschermt de zuivere religie en verbiedt al wat daartegen ingaat. Ook heeft zij te zorgen voor een goed stelsel van kerkregering. Alles wat met Gods Woord strijdt, moet in de wet verboden worden. De censuur moet met het zwaard der overheid worden verricht.

In een rijk waar de ware dienst van God niet wordt gekend, moet de overheid zich hoeden om zich heerschappij aan te matigen over het geloof en de religie, omdat God alleen daarover heerschappij voert. In de christelijke staat behoort heel het volk tot de ware kerk en dan moet de overheid die ware kerk verzorgen. Het is niet haar taak uit eigen hoofde te zeggen wat de ware godsdienst is. Als er geen eenstemmigheid is in het volk omtrent de godsdienst, moet de magistraat ter wille van de rust in het rijk deze onenigheid dulden. Maar ook dan moet alles wat de bloei der kerken en scholen kan schaden, worden tegengestaan, moeten ketterse geschriften worden verboden, de atheïsten en afvalligen en afgodendienaars worden gestraft. ${ }^{56}$

Althusius ging uit van een religieus homogene samenleving. ${ }^{57}$ De idee van publieke tolerantie in een plurale samenleving is bij deze calvinist nog ver te zoe-

55 O. O’Donovan \& J. Lockwood O'Donovan, From Irenaeus to Grotius - A sourcebook in christian political thought, Grand Rapids (VS)/ Cambridge (VK) 1999, 758 e.v.: 'There is in his theopolitical conception of church-commonwealth relations an Erastian tendency to suppress tensions between the ecclesiastical and civil orders and to invest their coordinated political existence with salvific value.'

56 J. Althusius, Politica Methodice Digesta, hoofdstuk 7, par. 4-7; A. Zijlstra, Tenzij, Amsterdam 1950, p. 317-318.

57 'Er entschied sich für eine politische Theorie, die die Verfassung eines religiös homogenen Gemeinwesens beschrieb.' W. Schmidt-Biggeman, 'Souveränität, Toleranz, Widerstand. Skizzen zu politischen Aporien aus dem konfessonellen Zeitalter', in: N. Brieskorn \& M. Riedenauer (red.), Suche nach Frieden: Politische Ethik in der Frühen Neuzeit III, Stuttgart 2003, p. 51. 
ken. Wel heeft hij zo bereikt dat Emden een gereformeerd bolwerk kon blijven in een overwegend lutherse omgeving.

Maar de tolerantie-idee won in de zeventiende eeuw wel veld, ook bij gereformeerden in Duitsland. Keurvorst Frederik Willem van Brandenburg, die gereformeerd was, vaardigde in zijn land een tolerantie-edict uit, waarin eenieder vrijheid van godsdienst werd gewaarborgd. Daarmee bood hij de ruimte die in de Vrede van Augsburg (1555) aan andersdenkenden ontzegd was. Deze keurvorst was een groot vereerder van prins Willem van Oranje, de grootvader van zijn vrouw Louise Henriëtte (een dochter van prins Frederik Hendrik). ${ }^{58}$

\section{Evaluatie en conclusie}

Groen van Prinsterer schreef eens: 'Het is de Reformatie, die door het recht op te vorderen van persoonlijke verantwoordelijkheid en onafhankelijkheid, den weg tot de vrijheid van geweten en tot het recht van het persoonlijk onderzoek heeft gebaand. ${ }^{59}$ In dezelfde tijd noemde Kuyper het calvinisme de oorsprong en waarborg van onze constitutionele vrijheden. ${ }^{60}$ Uit dit artikel blijkt dat daar wel wat op af te dingen is. ${ }^{61}$

In zijn Stone-lezing in Princeton in 1898 over het calvinisme en de staatkunde is Kuyper terecht voorzichtiger. Het netelige van de kwestie ligt, zo zegt hij, 'in de eenparige en eenstemmige betogen van Calvijn en zijn epigonen, die juist de tussenkomst van de overheid in de zaak van de religie vorderen. En nóg sterker spreekt dit netelige in het niet te loochenen feit, dat het niet zelden baptisten en remonstranten waren, die nu drie eeuwen geleden, dit stelsel van de vrije kerk tegen het calvinisme verdedigd hebben.' 62

De overheden in de Nederlandse Republiek van de zeventiende eeuw waren nog niet bereid tot algehele publieke gelijkberechtiging van aanhangers van een andere confessie. Frijhoff vindt daarom co-existentie een betere term dan tolerantie. ${ }^{63}$ Daar valt bij aan te tekenen dat ook de term tolerantie nog een verhouding van ongelijkwaardigheid impliceert: een meerderheid of een machthebber tolereert een minderheid. Wettelijke gelijkberechtiging kwam pas vanaf de negentiende eeuw in zicht.

W. Aalders, Luther en de angst van het westen - Een pleidooi voor de rechtsstaat, Den Haag 1982, p. 115.

59 G. Groen van Prinsterer, De Anti-Revolutionnaire en Confessionele Partij in de Nederlands Hervormde Kerk, Goes 1954, p. 131 (vertaling door A.J. van Dam van een Franstalig boek uit 1860).

60 Titel van een lezing van dr. A. Kuyper in 1873, uitgegeven in Amsterdam in 1874.

61 Zo ook J.C. Baak, Het Calvinisme oorsprong en waarborg onzer constitutioneele vrijheden?, Amsterdam 1945.

62 Kuyper 2008, p. 109.

63 W.Th.M. Frijhoff, 'Toleranz - Interkonfessionelles Zusammenleben in den Nederlanden in de frühen Neuzeit', in: H. Lademacher e.a. (red.), Ablehung - Duldung - Anerkennung, Toleranz in den Niederlanden und in Deutschland. Ein historischer und aktueller Vergleich, Münster/New York/München/Berlijn) 2004, p. 173. 
Toch valt niet te ontkennen dat een vrije, dat wil zeggen niet aan de staatsmacht onderworpen kerk juist opbloeide in de landen die onder invloed van het calvinisme kwamen. ${ }^{64}$ Dat is een aanwijzing dat toch met goed recht kan worden betoogd dat het calvinisme een positieve bijdrage heeft geleverd aan publieke tolerantie, en wel door zijn nadruk op de persoonlijke verantwoordelijkheid van de mens tegenover God. Daarin past geen dwang, noch van een kerkelijk instituut, noch van de overheid. Zo kon Groen van Prinsterer een stelling van Daniël Chantepie de la Saussaye (1818-1874) onderschrijven: 'De gelijkheid in rechten van alle godsdienstige gezindten is niet in strijd met de protestantsch-gereformeerde beginselen, mits de goddelijke wet, die door alle die gezindten gelijkelijk erkend wordt, als de hoogste wet ook voor den staat geldt.' 65

Ook Max Weber (1864-1920) rekent het calvinisme onder de bronnen van de tolerantie. Bij Willem van Oranje was het in zijn ogen een zaak van puur politieke staatsraison, en in Holland speelden ook handelsbelangen een rol, maar een factor was ook de calvinistische spiritualiteit met haar idee van predestinatie, die impliciet uitsloot dat de staat door middel van intolerantie de religie echt zou kunnen bevorderen. ${ }^{66}$

Kuyper acht het dan ook geen toeval dat 'de vrije kerk uitsluitend opbloeide in die landen, die onder de beademing van het calvinisme kwamen, te weten in Zwitserland, Nederland, Engeland, Schotland en de Verenigde Staten'. ${ }^{67}$ Sap sluit hierbij aan als hij schrijft: 'Ondanks de intolerantie van veel calvinisten, hebben calvinisten een buitengewoon belangrijke randvoorwaarde geschapen voor democratie en tolerantie, door op te komen voor het type van de vrije kerk. Hiermee streden de vroege calvinisten in Frankrijk eerder feitelijk dan principieel krachtig voor gewetensvrijheid. De ironie wil dat dit vrije kerktype tegelijkertijd de doorbreking betekende van het eigen theocratische ideaal, en uiteindelijk werd zelfs de weg vrij gemaakt voor de scheiding van kerk en staat.' Hij noemt dan ook het vroege calvinisme een van de randvoorwaarden voor het ontstaan van de democratische rechtsstaat. ${ }^{68}$

Wij sluiten ons bij deze conclusie aan. Het heeft de calvinisten enige tijd gekost voordat zij de consequenties van hun theologische inzichten omtrent de verhouding van de mens tot God konden doortrekken naar de verhoudingen in een pluriforme samenleving. En soms gingen minder diepe overwegingen bij de omslag in hun denken voorop. Maar de onderliggende gedachtegangen die zo geleidelijk openbaar werden, hebben niettemin Europa op het punt van de geestelijke vrijheden ingrijpend veranderd.

In onze tijd begint juist het seculiere denken moeite te krijgen met het tolereren van gelovigen die hun normen en waarden aan een Hogere instantie ontlenen.

64 Kuyper 2008, p. 111.

65 G. Groen van Prinsterer, Nederlandsche Gedachten, 1871, 3e jaargang, p. 58.

66 M. Weber, Die protestantische Ethik I, Hamburg/Gütersloh: Winckelmann 1979, p. 224.

67 Kuyper 2008, p. 111.

68 Sap 1993, p. 109 en 344. 
Dat wordt wel aangeduid als Verlichtingsfundamentalisme. Hedendaagse seculieren, zo merkt de Canadese neocalvinistische filosoof James Smith op, zijn soms zo zeker van hun eigen gelijk, dat ze niet geneigd zijn tolerant te zijn tegenover wie het niet met hen eens zijn, of te wachten tot die anderen meekomen met 'de goede kant van de geschiedenis'. 'Er zijn dus grote vragen te stellen bij het pluralisme van links dat de laatste tijd geduld noch tolerantie noch nederigheid heeft laten zien. ${ }^{69}$ Daartegenover blijft een christelijke overtuiging die afziet van machtsuitoefening ter ondersteuning van het geloof, maar opkomt voor de vrijheid van religie binnen de publieke samenleving, van wezenlijke waarde. 